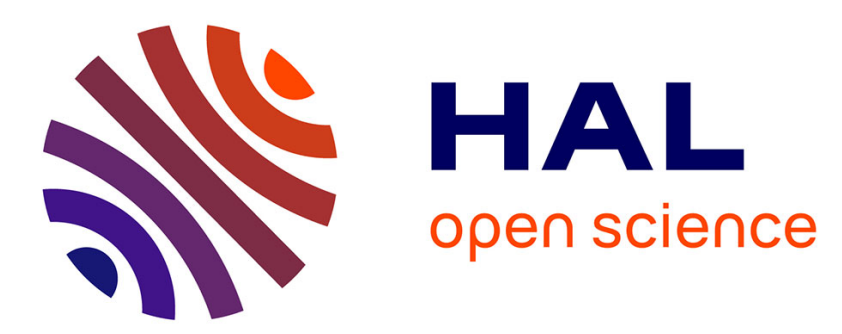

\title{
Changes within collembolan communities in windthrown European montane spruce forests 2 years after disturbance by fire
}

\author{
Čuchta, Miklisová, Kováč
}

\section{To cite this version:}

Čuchta, Miklisová, Kováč. Changes within collembolan communities in windthrown European montane spruce forests 2 years after disturbance by fire. Annals of Forest Science, 2012, 69 (1), pp.81-92. 10.1007/s13595-011-0114-y . hal-00930683

\section{HAL Id: hal-00930683 \\ https://hal.science/hal-00930683}

Submitted on 1 Jan 2012

HAL is a multi-disciplinary open access archive for the deposit and dissemination of scientific research documents, whether they are published or not. The documents may come from teaching and research institutions in France or abroad, or from public or private research centers.
L'archive ouverte pluridisciplinaire HAL, est destinée au dépôt et à la diffusion de documents scientifiques de niveau recherche, publiés ou non, émanant des établissements d'enseignement et de recherche français ou étrangers, des laboratoires publics ou privés. 


\title{
Changes within collembolan communities in windthrown European montane spruce forests 2 years after disturbance by fire
}

\author{
Peter Čuchta • Dana Miklisová • L'ubomír Kováč
}

Received: 11 May 2011 /Accepted: 11 July 2011 /Published online: 4 August 2011

(C) INRA and Springer Science+Business Media B.V. 2011

\begin{abstract}
- Context In July 2005, a wildfire occurred in windthrown spruce forests in High Tatra Mountains and damaged roughly 229 ha of previously clear-cut area.

- Aims The present study focuses on assessing the influence of fire disturbance upon collembolan communities and compares the subsequent development of the model communities at burnt and unburnt stands 2 years after fire disturbance.

- Methods Three different treatments were selected for the study: REF stands - intact forest stands; EXT standsclear-cut windthrown stands; and FIR stands-clear-cut windthrown stands subsequently damaged by wildfire. The study of soil microarthropods was carried out in three stands of each treatment, from soil samples taken in April and September of 2007. For statistical evaluation of results repeated measure analysis of variance and cluster analysis with indicator values were used.

- Results Total material comprised of 3,632 specimens with 56 collembolan species identified. The highest Collembola abundance means were recorded in FIR stands, with the same parameter being significantly lower in REF and EXT stands. The mathematical methods demonstrated clear
\end{abstract}

Handling Editor: François Lieutier

P. Čuchta $(\bowtie) \cdot$ L. Kováč

Institute of Biology and Ecology, Faculty of Science,

P. J. Šafárik University,

Moyzesova 11,

Košice 04001, Slovak Republic

e-mail: peter.cuchta@post.sk

D. Miklisová

Parasitological Institute, Slovak Academy of Sciences, Hlinkova 3,

Košice 04001, Slovak Republic differences in the collembolan communities between the different treatments studied.

- Conclusion The present study showed that natural wildfire may increase abundance and species richness of soil Collembola in mountain spruce forests previously damaged by windthrow.

Keywords Fire disturbance $\cdot$ Collembola $\cdot$ Spruce forest . Windthrow $\cdot$ High Tatra Mountains

\section{Introduction}

Forest fire can drastically change the structure of the forest ecosystem. The overall effects of fire are complex, ranging from the removal of aboveground biomass to affecting the physical, chemical and biological components of soil ecosystems. Fire produces a broad spectrum of effects that depend on duration, fuel load and combustion, vegetation type, climate, topography, soil and area burnt (Mabuhay et al. 2006). Forest fire could influence the soil microarthropods assemblages; direct killing by the blaze and indirect impacts by altering their habitats by changing the composition of forest vegetation or by disturbing the balance of soil chemicals, water levels and $\mathrm{pH}$. In addition, burning out of litter and other organic matter may cause the depletion of food source for soil microarthropods since most of them are decomposers of organic materials in forest floor and their associates (Kim and Jung 2008).

Fires are often major features of forest disruption and renovation. Widely investigated is their role in altering floristic composition, promoting tree regeneration, enhancing timber production and conditioning human ecology. Prescribed fires are increasingly employed as a management strategy in the conservation of fire-dependent species 
by controlling the proliferation of native and non-native invasive plants (Coleman and Rieske 2006). Burning makes conditions more favourable for the development of tree seedlings, but, at the same time, heavily alters the environment of soil decomposer organisms (Haimi et al. 2000). On the other side, prescribed burning become more common for conservational reasons in order to allow pyrophilous species to persist. These species are dependent on fire for their long-term survival either directly or indirectly by being favoured by the disturbance. As in natural fires, the biological outcome of such burning operations can vary widely but can partly be controlled by choice of burning technique and by timing of the burning in relation to certain weather conditions (Wikars and Schimmel 2001).

There are numerous findings on the effects of fire on soil properties. The extent and duration of these effects depend firstly upon fire severity, which, in turn, is controlled by several environmental factors, that affect the combustion process, such as amount, nature and moisture of live and dead fuel, air temperature and humidity, wind speed and topography of the site (Certini 2005). Fire severity, or the amount of organic material consumed by a fire, is a key component of the fire regime that influences patterns of post-fire regeneration. Soil burn severity influences both the availability of plant propagules and the physical properties of the post-fire soil (Johnstone and Stuart Chapin 2006). Depth of burn determines patterns of survival, colonisation and regrowth of plants after fire (Wikars and Schimmel 2001). According to Malmström et al. (2009), fire severity (depth of burn) is more decisive than fire intensity (heat release) for the long-term recovery of soil fauna, whereas fire intensity determines the acute mortality of animals.

The effects of burning on the physico-chemical properties of soil are well documented. During burning, temperature and moisture conditions change drastically. Soil $\mathrm{pH}$ increases thereby increasing the cation exchange capacity and reducing solubility of ions. Fire modifies the levels of soil nutrients, resulting mainly in the loss of total nitrogen (Kutiel and Naveh 1987). During a fire, nutrients are abruptly mineralised and the decrease in food source may affect soil invertebrates. The effects of fire may include large flux of nutrients leaving the ecosystem through volatilisation and rapid mineralization of nutrients, losses of nutrients through accelerated erosion and leaching, adverse changes in hydrology degradation of soil physical properties and losses in microbial populations and associated processes (Sileshi and Mafongoya 2006).

Generally, the direct effects of fire on soil-dwelling invertebrates are less marked than those on microorganisms, due to the higher mobility that enables invertebrates a greater potential to escape heating by burrowing deep into the soil. However, the indirect effects of fire, particularly litter mass reduction, are effective at decreasing drastically both total mass and number of species of soil-dwelling invertebrates (Certini 2005). Arthropods suffer exposure to greater extremes of temperature, light and moisture, resulting in subsequent habitat loss. Those lacking adaptations to these fire-induced changes are eliminated. However, arthropods protected from fire disturbance either by life history traits, location during fire, or behavioural characteristics that prevent mortality, can benefit following fire because of potential reductions in competitors and predators, increases in dead prey for scavengers, and more nutritional plant hosts (Coleman and Rieske 2006).

In November 2004, severe wind struck the spruce forest stands of the High Tatras National Park and damaged an area of roughly 12,600 ha (about $50 \%$ ) of the local spruce forests (Faltan et al. 2008). At the majority of the damaged spruce stands in the High Tatra Mts., clear-cut management was performed and fallen trunks were harvested; whereas only a small area of the damaged spruce forest was left to natural succession. In July 2005, a wildfire occurred in windthrown stands previously clear-cut and harvested with roughly 229 ha of the damaged area (Kunca and Zúbrik 2006). The present paper is associated with the broader study focused on the initial succession of soil Arthropoda communities with the special reference to Collembola. The investigation was carried out at three differently managed forest stands mentioned above: unharmed (reference) forest stand, windthrown forest stand subsequently clear-cut and unmanaged windthrown forest stand left to the natural succession. The goal of this study was to assess the effect of wildfire on collembolan assemblages at area burnt 2 years after disturbance in comparison with areas of forest stands under different treatment. Based on literature data, we hypothesised the decrease in abundance and diversity of collembolan communities at burnt stands with potential recovery of soil microarthropods after the fire.

\section{Material and methods}

Three different treatments were selected in the High Tatras National Park for the study (Table 1):

REF stands (reference, control stands) - intact forest stands undamaged by severe wind, locality Smrekovec near the Vyšné Hágy village $\left(49^{\circ} 7^{\prime} 22.3^{\prime \prime} \mathrm{N}, 20^{\circ} 6^{\prime} 5.6^{\prime \prime} \mathrm{E}\right.$, $1,268 \mathrm{~m}$ above sea level (asl); 497'19.1' $\mathrm{N}, 20^{\circ} 6^{\prime} 12.1^{\prime \prime}$ E, $1,241 \mathrm{~m}$ asl; $49^{\circ} 7^{\prime} 16.5^{\prime \prime} \mathrm{N}, 20^{\circ} 6^{\prime} 12.6^{\prime \prime} \mathrm{E}, 1,237 \mathrm{~m}$ asl). Forest floor covered with patches of Polytrichum sp. moss cushions, coniferous litter (spruce needles), Vaccinium myrtillus, grasses (Calamagrostis villosa, Avenella flexuosa) and Oxalis acetosella patches; soil profile: $0-2 \mathrm{~cm}$ litter (spruce needles), 2-6 cm humus 
Table 1 Characteristics of study stands (Gömöryová et al. 2008)

$S$ south, $E$ east; for abbreviations of study stands, see text

\begin{tabular}{llll}
\hline & REF & EXT & FIR \\
\hline Altitude (m asl) & $1,100-1,250$ & $1,040-1,260$ & $1,000-1,200$ \\
Aspect & SE & S & SE \\
Slope (\%) & $10-20$ & 10 & $5-10$ \\
Tree species composition (\%) & Spruce 80, larch 20 & Spruce 90, larch 10 & Spruce 70, larch 30 \\
Stand age & $120 / 25$ & 80 & 80 \\
Soil type & Dystric Cambisol & Dystric Cambisol & Dystric Cambisol \\
Dominant humus form & Mor & Mor & Mor \\
Parental rock & Moraine & Moraine & Stone-centred polygons \\
\hline
\end{tabular}

layer, 6-10 (15) $\mathrm{cm}$ dark brown mineral layer, under $15 \mathrm{~cm}$ and lower transition to paler mineral layer with stones.

EXT stands - windthrown forest stands subsequently clear-cut and tree stumps harvested, locality Danielov dom near the Nová Polianka village $\left(49^{\circ} 7^{\prime} 17.4^{\prime \prime} \mathrm{N}, 20^{\circ} 9^{\prime}\right.$ 45.6" E, 1,066 m asl; 49 $7^{\circ} 19.6^{\prime \prime} \mathrm{N}, 20^{\circ} 9^{\prime} 46.3^{\prime \prime} \mathrm{E}, 1,070 \mathrm{~m}$ asl; $49^{\circ} 7^{\prime} 22^{\prime \prime} \mathrm{N}, 20^{\circ} 9^{\prime} 48.2^{\prime \prime} \mathrm{E}, 1,074 \mathrm{~m}$ asl). Dense growths of grass and herbs covered the stand with dominating C. villosa and A. flexuosa; soil profile: 0 $2 \mathrm{~cm}$ litter (spruce needles), 2-6 cm humus layer, 6-10 (15) $\mathrm{cm}$ dark brown mineral layer, $10-15 \mathrm{~cm}$ transition to grey or pale brown mineral layer with stones.

FIR stands-windthrown forest stands clear-cut and subsequently damaged by wildfire, locality Tatranské Zruby village $\left(49^{\circ} 8^{\prime} 11.58^{\prime \prime} \mathrm{N}, 20^{\circ} 11^{\prime} 55.26^{\prime \prime} \mathrm{E}, 1,080 \mathrm{~m}\right.$ asl; $49^{\circ} 8^{\prime} 10.92^{\prime \prime} \mathrm{N}, 20^{\circ} 11^{\prime} 52.38^{\prime \prime} \mathrm{E}, 1,084 \mathrm{~m}$ asl; $49^{\circ} 8^{\prime}$ $10.98^{\prime \prime} \mathrm{N}, 20^{\circ} 11^{\prime} 50.7^{\prime \prime} \mathrm{E}, 1,088 \mathrm{~m}$ asl).

The area was covered by thin layer of ash remnants and by dense growths of rosebay willowherb (Chamaenerium angustifolium) and grasses (C. villosa, A. flexuosa); soil profile: $0-6 \mathrm{~cm}$ remnants of burnt litter and upper humus layer, 6-10 (15) cm dark brown mineral layer, $10-15 \mathrm{~cm}$ transition to grey or pale brown mineral layer with stones.

Soil samples were taken in April and September 2007. Within each treatment, three stands were selected in reciprocal distance of roughly $100 \mathrm{~m}$. Sampling plots were about $25 \times 25 \mathrm{~m}$ in area; during sampling, six replicate soil cores were taken randomly with a steel corer from each individual plot. The samples represented soil cores of $3.6 \mathrm{~cm}$ in diameter $\left(10 \mathrm{~cm}^{2}\right.$ in area) to a maximum depth of $7-12 \mathrm{~cm}$ (depending on the soil depth). The microarthropods were subsequently extracted in a modified high-gradient apparatus (Crossley and Blair 1991) in the laboratory for 7 days. Collembola were selected and determined to species level using key for Symphypleona (Bretfeld 1999), Poduromorpha (Fjellberg 1998), Hypogastruridae (Thibaud et al. 2004), Isotomidae (Potapov 2001), Onychiurinae (Pomorski 1998) and Tullbergiinae (Zimdars and Dunger 1994).
Community parameters were calculated for comparison of the collembolan assemblages at the stands under study: abundance (A), mean species richness (S), mean Shannon index of diversity $\left(\mathrm{H}^{\prime}\right)$ and mean Pielou index of evenness $\left(\mathrm{J}^{\prime}\right)$. Since the samples were taken repeatedly from the same study stands during two samplings, two factorial repeated measure analysis of variance (ANOVA; stand and sampling date) was used to test differences between Collembola abundance, mean diversity indices and soil characteristics. A Box-Cox transformation was performed to normalise abundance data and number of species prior to statistical testing, other data were normally distributed. Post hoc comparison testing (Fisher's least significant difference test) was used to determine the significant differences between stands and stands $\times$ dates. Kruskal-Wallis non-parametric test was used to determine the significant differences between mean abundance values of dominant collembolan species in particular study stands. STATISTICA 9.0 software package (StatSoft, Inc. 2009) was used for both aforementioned analyses.

Similarity of the Collembola communities of particular stands was evaluated by cluster analysis (Ward's method, Euclidean distance) of logarithmically $\ln (x+1)$ transformed quantitative data using STATISTICA 9.0 (StatSoft, Inc. 2009). The cluster diagram obtained was used for typology of stands in subsequent indicator values (IndVal) analysis (Dufréne and Legendre 1997). Indicator species were defined as the most characteristic species of each group, found mostly in a single group of the typology (specificity) and present in the majority of the stands or samples belonging to that group (fidelity). The indicator value of a given species for a given group of stands is a multiple of specificity and fidelity, and is expressed as a percentage. The indicator value of a given species for a typology of stands is defined as the maximum over all groups of the typology (IndVal). A maximum value in the IndVal index is reached if all individuals of a species are found in a single group of stands and when the species occurs in all stands for that group. A threshold level of $25 \%$ for the index was accepted by Dufréne and Legendre (1997), which assumes that theoretically an important assemblage species is 
present in at least $50 \%$ of one stand cluster and that its relative abundance for that cluster reaches at least $50 \%$. Afterward, a significance test of observed maximal indicator values for a given species was applied with 1,000 permutations. A FORTRAN programme (2004) was used to compute the indicator value index and perform the randomization testing procedure.

Soil $\mathrm{pH}$ was measured potentiometrically using glass electrode and reference calomel electrode as active $\mathrm{pH}$ in water $\left(\mathrm{pH} / \mathrm{H}_{2} \mathrm{O}\right)$ and replacement $\mathrm{pH}$ in $1 \mathrm{M}$ water solution of potassium chloride $(\mathrm{pH} / \mathrm{KCl})$. Soil/water ratio was 1:2.5 (Kubíková 1970). Soil carbon content was measured according to Králová et al. (1991). Dry soil was modified to have maximal size of soil particles $0.25 \mathrm{~mm}$. Soil organic matter was oxidised by chrome-sulphuric mixture under increased temperature and surplus dichromate was determined by reversal titration through Mohr's salt to diphenylalanine indicator. Total $\mathrm{N}$ content was measured in dried $\left(60^{\circ} \mathrm{C}\right)$ and finely milled soil samples using a $\mathrm{NC}$ elemental analyser (ThermoQuest, Germany; Tahovská et al. 2010). Soil phosphorus content was measured by mineralizing of dry soil with modified soil particles of maximal size $0.25 \mathrm{~mm}$ with perchloric acid (Sommers and Nelson 1972) and orthophosphate ions were subsequently allocated by ammonium molybdate and ascorbic acid (Murphy and Riley 1962; Watanabe and Olsen 1965). Soil sodium, potassium and calcium were measured according Kubíková (1970) by ionselective electrodes during wiggling dry fine soil with $1 \%$ solution of citric acid (ratio 1:5) and using accessory methods (Nedoma 1990). Soil moisture was analysed gravimetrically.

\section{Results}

Recorded soil-chemical characteristics of the studied spruce forest stands showed differences in content of soil carbon and nitrogen as well as in average soil moisture and soil acidity (Table 2). In REF stands, we recorded significantly higher values of both carbon $(p<$ $0.005)$ and nitrogen $(p<0.005)$ content than in FIR stands or EXT stands. We observed the highest values of soil moisture and the lowest $\mathrm{pH}$ in REF stands. Differences of soil $\mathrm{pH}$ between stands $(p<0.0005$ for REF-EXT stands and $p<0.005$ for REF-FIR stands) were statistically significant. The highest values of total phosphorus content were recorded in FIR stands followed by REF stands and the lowest values were found in EXT stands. Difference in total phosphorus content between FIR and EXT stands was statistically significant $(p<0.05)$. There were no significant differences recorded between study stands in content of soil sodium, potassium or calcium.

The material comprised of 3,632 specimens of Collembola with totally 56 species identified. The highest total abundance mean $\left(54,500\right.$ ind. $\left.\mathrm{m}^{-2}\right)$ was recorded in windthrown stands clear-cut and subsequently damaged by wildfire (FIR stands), much lower values of the parameter $\left(24,000\right.$ ind. $\left.\mathrm{m}^{-2}\right)$ were observed in intact control forest stands (REF), and the lowest $(22,872$ ind. $\mathrm{m}^{-2}$ ) in windthrown stands subsequently clear-cut and tree stumps harvested (EXT). FIR1 $(p<0.05)$ and FIR3 $(p<$ 0.005 ) stands in April were significantly different in abundance from almost all other stands (REF, EXT and FIR). Species richness recorded in individual study stands was 43 species in FIR, 38 in REF and 32 in EXT stands, respectively (Table 3). Repeated ANOVA measure of number of species confirmed significant influence of sampling date $(F(1,45)=17.20, p<0.001)$. Highest average value of Shannon index was observed in REF stands $(1.56 \pm 0.22)$, followed by FIR stands $(1.42 \pm 0.20)$ and lowest average value was recorded in EXT stands (1.35 \pm 0.31). Repeated ANOVA measure of Shannon index confirmed significant influence of sampling date $(F(1$,

Table 2 Soil characteristics of study stands in the High Tatra Mts.

\begin{tabular}{lcccccrrrr}
\hline & REF1 & REF2 & REF3 & EXT1 & EXT2 & EXT3 & FIR1 & FIR2 & FIR3 \\
\hline $\mathrm{W}[\%]$ & 42.78 & 40.92 & 42.78 & 44.75 & 37.01 & 33.90 & 39.53 & 35.37 & 31.84 \\
$\mathrm{SD}(\mathrm{W})$ & \pm 5.21 & \pm 13.41 & \pm 8.35 & \pm 8.43 & \pm 4.09 & \pm 10.23 & \pm 9.63 & \pm 4.77 & \pm 5.20 \\
$\mathrm{pH}$ & 3.38 & 3.26 & 3.43 & 4.06 & 4.17 & 4.14 & 3.72 & 4.03 & 4.06 \\
$\mathrm{C}[\%]$ & 13.57 & 17.29 & 17.26 & 9.29 & 10.06 & 9.16 & 11.03 & 8.05 & 8.06 \\
$\mathrm{~N}[\%]$ & 0.71 & 0.79 & 0.82 & 0.51 & 0.58 & 0.53 & 0.62 & 0.52 & 0.49 \\
$\mathrm{P}_{\text {tot }}\left[\mathrm{mg}_{\mathrm{ngg}}{ }^{-1}\right]$ & 842 & 793 & 859 & 739 & 762 & 731 & 1,002 & 780 & 955 \\
$\mathrm{Na}\left[\mathrm{mg} \cdot \mathrm{kg}^{-1}\right]$ & 92 & 48 & 20 & 44 & 32 & 56 & 36 & 28 & 28 \\
$\mathrm{~K}\left[\mathrm{mg} \cdot \mathrm{kg}^{-1}\right]$ & 148 & 64 & 60 & 94 & 142 & 72 & 88 & 92 & 68 \\
$\mathrm{Ca}\left[\mathrm{mg} \cdot \mathrm{kg}^{-1}\right]$ & 36 & 100 & 30 & 32 & 56 & 24 & 68 & 42 & 148 \\
\hline
\end{tabular}

$W$ average gravimetric soil moisture (\% of initial weight), $S D(W)$ standard deviation of moisture values, $p H$ soil acidity, $C$ soil carbon content (\% of initial weight), $N$ soil nitrogen content (\% of initial weight), $P_{t o t}$ total phosphorus content in the soil, $N a$ soil sodium content, $K$ soil potassium content, $\mathrm{Ca}$ soil calcium content; for abbreviations of study stands, see text 
Table 3 Ecological parameters of Collembola communities in study stands in the High Tatra Mts.

\begin{tabular}{|c|c|c|c|c|c|c|c|}
\hline & Apr & Sep & Apr & Sep & Apr & Sep & SD Average \\
\hline & EXT1 & EXT1 & EXT2 & EXT2 & EXT3 & EXT3 & \\
\hline A [ind. $\mathrm{m}^{-2}$ ] & $25,000^{\mathrm{a}}$ & $21,000^{\mathrm{a}}$ & $14,167^{\mathrm{a}}$ & $25,833^{\mathrm{a}}$ & $17,400^{\mathrm{a}}$ & $33,833^{\mathrm{a}}$ & $22,872 \pm 6,360$ \\
\hline $\mathrm{S}$ & 20 & 23 & 17 & 19 & 14 & 13 & $17.67 \pm 3.78$ \\
\hline$S$ total & 32 & & & & & & \\
\hline $\mathrm{H}^{\prime}$ & 1.60 & 1.64 & 1.10 & 1.71 & 0.92 & 1.09 & $1.35 \pm 0.31$ \\
\hline \multirow[t]{2}{*}{$\mathrm{J}^{\prime}$} & 0.89 & 0.83 & 0.86 & 0.91 & 0.53 & 0.68 & $0.78 \pm 0.14$ \\
\hline & FIR1 & FIR1 & FIR2 & FIR2 & FIR3 & FIR3 & Average \\
\hline A [ind. $\mathrm{m}^{-2}$ ] & $57,000^{\mathrm{ac}}$ & $38,167^{\mathrm{b}}$ & $36,500^{\mathrm{bc}}$ & $27,167^{\mathrm{b}}$ & $132,667^{\mathrm{a}}$ & $35,500^{\mathrm{b}}$ & $54,500 \pm 36,091$ \\
\hline $\mathrm{S}$ & 16 & 17 & 21 & 25 & 19 & 11 & $18.17 \pm 4.75$ \\
\hline$S$ total & 43 & & & & & & \\
\hline $\mathrm{H}^{\prime}$ & 1.50 & 1.41 & 1.22 & 1.82 & 1.36 & 1.24 & $1.42 \pm 0.20$ \\
\hline \multirow[t]{2}{*}{$\mathrm{J}^{\prime}$} & 0.81 & 0.77 & 0.76 & 0.85 & 0.68 & 0.81 & $0.78 \pm 0.05$ \\
\hline & REF1 & REF1 & REF2 & REF2 & REF3 & REF3 & Average \\
\hline A [ind. $\left.\mathrm{m}^{-2}\right]$ & $27,167^{\mathrm{a}}$ & $35,167^{\mathrm{a}}$ & $14,667^{\mathrm{a}}$ & $26,833^{\mathrm{a}}$ & $21,500^{\mathrm{a}}$ & $18,667^{\mathrm{a}}$ & $24,000 \pm 6,640$ \\
\hline $\mathrm{S}$ & 22 & 23 & 18 & 25 & 14 & 18 & $20.00 \pm 4.05$ \\
\hline $\mathrm{S}$ total & 38 & & & & & & \\
\hline $\mathrm{H}^{\prime}$ & 1.46 & 1.80 & 1.29 & 1.78 & 1.28 & 1.72 & $1.56 \pm 0.22$ \\
\hline $\mathrm{J}^{\prime}$ & 0.78 & 0.81 & 0.77 & 0.82 & 0.78 & 0.87 & $0.81 \pm 0.03$ \\
\hline
\end{tabular}

$A$ mean abundance, $S$ average species richness, $S$ total total species richness, $H^{\prime}$ Shannon's diversity, $J^{\prime}$ Pielou's evenness, significant differences of abundance $(p<0.05)$ between individual stands within particular treatment are indicated by different lowercase letters in every row separately; for abbreviations of study stands, see text

$45)=7.592, p<0.01)$. The same trend was observed also in Pielou index with the highest average value in REF stands $(0.81 \pm 0.03)$ and lower average value recorded in FIR stands $(0.78 \pm 0.05)$ and EXT stands $(0.78 \pm 0.14)$. Repeated ANOVA of Pielou index confirmed significant influence of microsite $(\mathrm{F}(8,45)=3.596, p<0.01)$. The most abundant species at all study stands were Folsomia penicula $\left(A=6,969\right.$ ind. $\left.\mathrm{m}^{-2}\right)$, Isotomiella minor $(A=$ 5,678 ind. $\left.\mathrm{m}^{-2}\right)$, Anurophorus laricis $\left(A=5,004\right.$ ind. $\left.\mathrm{m}^{-2}\right)$ and Protaphorura armata $\left(A=3,602\right.$ ind. $\left.\mathrm{m}^{-2}\right)$. Futhermore, IndVal analysis showed first two mentioned species, together with Pseudosinella horaki, to be characteristic for all study stands (Fig. 1).

We observed considerable differences within collembolan communities of individual study forest stands, especially in presence of individual species and mean abundance values of dominant ones. In FIR, A. laricis $(A=12,250$ ind. $\left.\mathrm{m}^{-2}\right)$, I. minor $\left(A=11,861\right.$ ind. $\left.\mathrm{m}^{-2}\right), F$. penicula $(A=$ 9,111 ind. $\left.\mathrm{m}^{-2}\right)$ and $P$. armata $\left(A=8,556\right.$ ind. $\left.\mathrm{m}^{-2}\right)$ were the most abundant. Comparing to other two forest stands we recorded, there are significantly higher mean abundance values of Ceratophysella armata $\left(A=2,833\right.$ ind.m ${ }^{-2}, p<$ $0.0005)$ and Ceratophysella denticulata $\left(A=2,639\right.$ ind. $\mathrm{m}^{-2}$, $p<0.0005)$. Protaphorura pannonica was abundant in FIR stands $\left(A=2,611\right.$ ind. $\left.{ }^{-2}\right)$ with noteworthy decrease of its abundance in $\operatorname{EXT}\left(A=1,328\right.$ ind.m $\left.{ }^{-2}\right)$, as well as in REF
$\left(A=361\right.$ ind.m $\left.{ }^{-2}\right)$. Several species were limited to FIR stands, e.g. C. denticulata, Desoria violacea, Endonura tatricola, Hymenaphorura dentifera, Mesaphorura florae, Mesaphorura tenuisensillata, Micranurida granulata, Orchesella flavescens, Protaphorura fimata and Archaphorura sp., however, except $C$. denticulata their abundances were very low. On the other hand, Friesea mirabilis, Lepidocyrtus lignorum and Tetracanthella fjellbergi had notably lower mean abundance in FIR stands and Lepidocyrtus cf. cyaneus, Pogonognathelus sp. and Tomocerus minor totally absented there.

In unburnt EXT, Anurophorus cuspidatus ( $A=$ 4,989 ind $\mathrm{m}^{-2}$ ) was the most abundant, followed by $A$. laricis $\left(A=2,761\right.$ ind. $\left.\mathrm{m}^{-2}\right)$ and I. minor $\left(A=2,533\right.$ ind. $\left.\mathrm{m}^{-2}\right)$, respectively. Folsomia manolachei, Micranurida pygmaea, Orchesella bifasciata, Parisotoma notabilis and Protaphorura campata were considerably more abundant there than in both REF and FIR stands. Lepidocyrtus serbicus, Mesaphorura yosii and Pseudachorutes laricis were limited in their occurrence to EXT stands. On the other side, significantly less abundant in EXT stands was $F$. penicula $(p<0.01)$. Notably, but not significantly less abundant was also P. armata. Folsomia inoculata, Megalothorax minimus, Mesaphorura macrochaeta, Protaphorura gisini, Willemia anophthalma and Willemia denisi totally absented there. 
Fig. 1 Cluster analysis of quantitative community data of Collembola in study stands in April and September 2007 in the High Tatra Mts. (Ward's method, relative Euclidean distance, $\ln (x+1)$ transformation) with the associated indicator species and indicator values (IndVal). All species with statistically significant $(p<$ 0.05 , except species at first level) indicator value $>25 \%$ are mentioned for stand cluster where they reached their maximum indicator value; for abbreviations of species, see Appendix

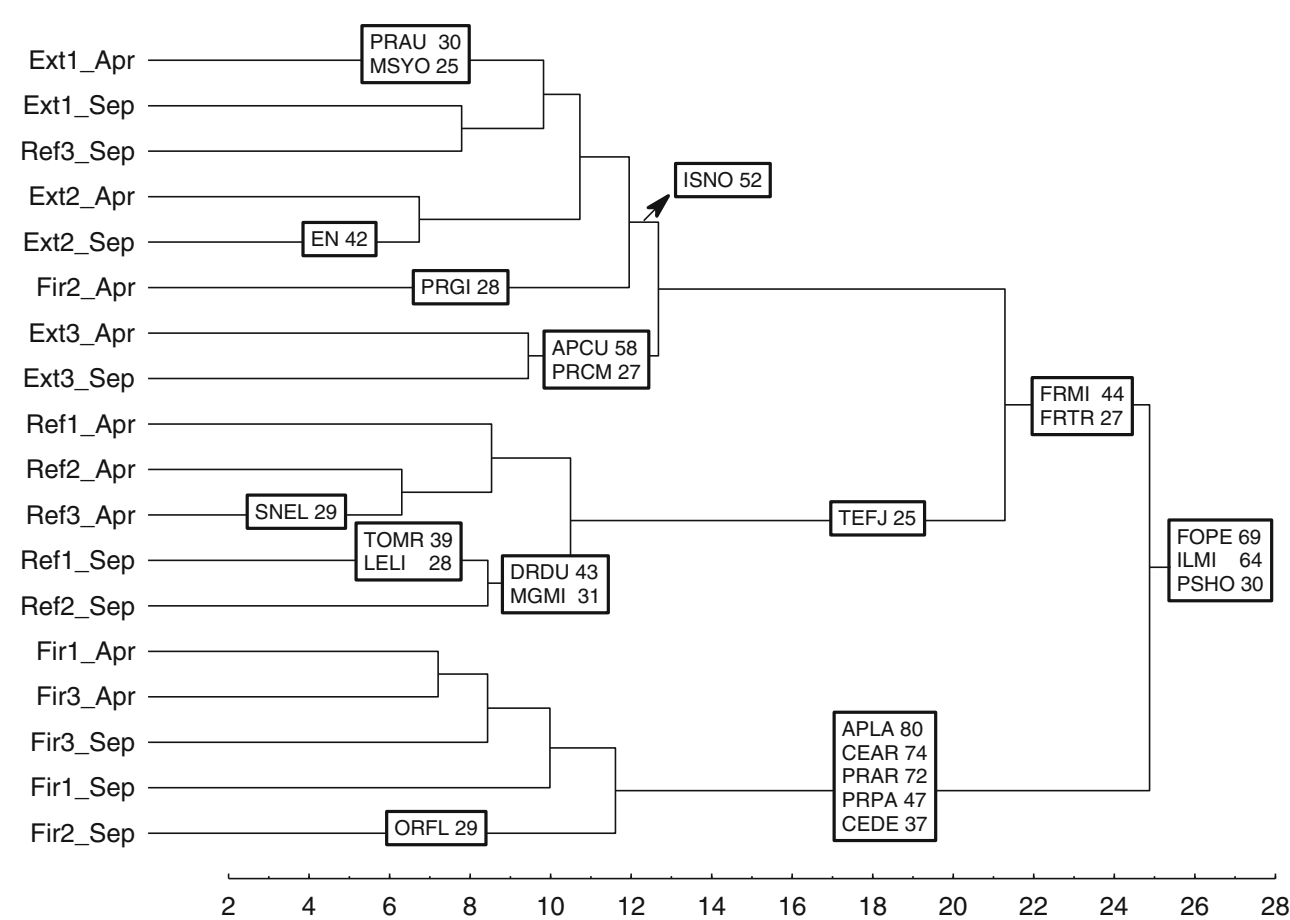

In REF, the most abundant species were $F$. penicula $\left(A=9,889\right.$ ind. $\left.\mathrm{m}^{-2}\right)$ and $I$. minor $\left(A=2,639\right.$ ind. $\left.^{-2}\right)$. Similarly with FIR stands $P$. $\operatorname{armata}\left(A=1,417\right.$ ind.m $\left.{ }^{-2}\right)$ was abundant there too. Comparing to both FIR and EXT stands, considerably higher abundance was observed in Desoria duodecemoculata, F. mirabilis, Friesea truncata, Pseudanurophorus binoculatus, P. horaki, Sminthurinus elegans, T. fjellbergi and T. minor. Several species were limited to REF stands, e.g. Allacma fusca, Ceratophysella sigillata, Neanura pseudoparva, Protaphorura subarmata, Pseudachorutes corticicolus and Thaumanura carolii. On the other hand, A. cuspidatus, M. pygmaea, Protaphorura aurantiaca, $P$. pannonica were notably less abundant in REF stands than in both EXT and FIR stands. A. laricis, Mesaphorura hylophila and O. bifasciata totally absented there.

The cluster analysis diagram of Collembola quantitative community data with the associated indicator species (IndVal) showed two main branches (Fig. 1). All species with statistically significant $(p<0.05$, except species at first level) indicator value $>25 \%$ are mentioned for stand cluster, where they reached their maximum indicator value. First, well-separated branch represents all three windthrown forest stands damaged by wildfire (FIR1, FIR2 and FIR3) from September and stands (FIR1 and FIR3) from April with $A$. laricis, $C$. armata, $C$. denticulata, $P$. armata and $P$. pannonica being specific in these stands. A second branch has two characteristic species, e.g. F. mirabilis and F. truncata, and it is divided into two marked sub-branches: (1) represented by all three reference forest stands (REF1, REF2 and REF3) from April and two stands (REF1 and REF2) from September with $T$. fjellbergi as specific species for these stands and (2) consists of all three windthrown stands with harvested wood (EXT1, EXT2 and EXT3) from both April and September together with one reference forest stand (REF3) from September and last of burnt stands (FIR2) from April. There were also some characteristic species of particular stands in lower levels of clustering distance. Observed differences between particular stands of the same treatment are caused by differences in total mean abundance values recorded for individual sampling seasons.

Significant positive correlations were found between abundance of several species and soil-chemical parameters. Abundance of $A$. laricis correlated with total phosphorus $(r=0.74, p<0.05)$ and calcium $(r=0.69, p<$ $0.05)$ content in the soil. Similarly, there were correlations found between total phosphorus $(r=0.86, p<0.005)$ and calcium $(r=0.72, p<0.05)$ content in the soil and abundance of $C$. armata. Another correlations between total soil phosphorus and abundance of P. armata $(r=0.75, p<$ $0.05)$ and $F$. penicula $(r=0.70, p<0.05)$ was observed. $I$. minor correlated with soil calcium $(r=0.80, p<0.01)$. Finally, correlations were recorded between content of soil carbon $(r=0.73, p<0.05)$, soil nitrogen $(r=0.70, p<$ $0.05)$, as well as soil moisture $(r=0.67, p<0.05)$ and abundance of $F$. mirabilis. 


\section{Discussion}

According to many studies of fire disturbance effect upon soil microarthropods (Henig-Sever et al. 2001; Wikars and Schimmel 2001; Dress and Boerner 2004; Coleman and Rieske 2006; Kim and Jung 2008; Malmström et al. 2009), the fire (prescribed or natural) negatively affected both abundance and species richness of soil microarthropods. One of the direct effects of the fire disturbance is considerable reduction of surface litter mass. There were found significant relationships between microarthropod abundance and litter mass, strongest for Collembola (Dress and Boerner 2004).

Furthermore, the abundance of microarthropods has been observed to increase over time following a disturbance by fire, indicating a recovery effect (Wikars and Schimmel 2001; Coleman and Rieske 2006). Contrary to the literature data, the present study showed an enormous increase of abundance within collembolan communities 2 years after a fire disturbance. Additionally, we found some species restricted to windthrown stands damaged by wildfire, however usually in a low abundance. In contrast to our results, Malmström et al. (2009) observed no recovery effect in their 5-year study of soil meso- and macrofauna dynamics after prescribed clear-cut burning in a boreal forest in central Sweden upon the soil meso- and macrofauna. Moreover, they found no species exclusive to the burnt area within these groups. In our study, however, we had different stand conditions, especially soil type and type of humus that are crucial for development of soil fauna communities (Ponge 2003). The study of Malmström et al. (2009) was conducted on orthic podzol with mor humus, organic profile being usually shallow, thus more sensitive to the fire. In our case we had dystric cambisol with thick organo-mineral layer determining better vertical distribution of soil fauna with less sensitivity to fire and better possibility to recover in situ after the disturbance. Our results are supported by Gömöryová et al. (2008) and Čerevková and Renčo (2009) who carried out the soilbiological observations in forest stands identical with our study in the High Tatra Mts in 2006, i.e. 1 year after the fire. The highest microbial activity in burnt stands was explained by high organic matter and water contents and by changed temperature regime as compared to the reference stand (Gömöryová et al. 2008). The FIR stands showed also the highest abundance of the free-living soil nematodes with bacterial feeders prevailing (Čerevková and Renčo 2009).

In the matter of collembolan abundance, we observed variability between particular stands of the same treatment, the most obvious in FIR stands. The most probable reason was the higher heterogeneity of the stands due to the mosaic terrain microtopography and variable soil thickness after the clearing treatment and fire disturbance. The apparent increase in Collembola abundance observed in FIR3 in spring (in all samples taken) was caused by a high abundance of several dominant species, especially I. minor and F. penicula (see Appendix).

Windthrow might have a positive effect on arthropod communities with time. According to Wermelinger et al. (2003), windthrow caused an overall increase in biodiversity compared to the intact forest. We observed the same trend in our study of the influence of the windthrow and consecutive changes in the soil environment upon soil microarthropods with special reference to Collembola in the High Tatra Mts (Čuchta et al. 2009). According to our results, clearing practices in the spruce forests damaged by severe wind slightly enhanced diversity of soil microarthropod groups and species diversity of Collembola during the first year after the wind calamity. On the other hand, this kind of management strikingly diminished quantities of soil microarthropods, indicating overall inhibition of the soil processes at sites with intensive forest management, i.e. clear-cut with removal of tree logs. In the present study, we recorded the lowest value of collembolan abundance in EXT stands and the lowest species richness, which is contrary to the results of our previous study (Čuchta et al. 2009). We assume that the temporary increase of species richness observed early after the windthrow had faded away. Dense growths of grass and herbs covered the ground after clear-cutting of the former spruce forest stands. Epigeic species characteristic of meadows or forest edges colonised these formerly forested areas as also observed by Rusek and Brůhová (2007) in the study of the impact of a bark beetle outbreak on epigeic collembolan communities in spruce forests in the Šumava National Park (Bohemia). On the other hand, populations of montane collembolan species decimated after the windthrow were banished or totally wiped out. Moreover, our hypothesis concerning the detrimental impact of clearing treatments on collembolan species richness 3 years after the wind calamity was confirmed by the lowest values of both diversity indices counted.

Haimi et al. (2000) studied responses of soil decomposer animals to wood-ash fertilisation and burning in a coniferous forest stand in central Finland. They applied different treatments: a control, two level of wood-ash fertilisation and a fire treatment mimicking prescribed burning. After 3 years, they found increased arthropod densities and total numbers of collembolans in all study stands with no effect from any of the treatments. According to Henig-Sever et al. (2001), the size of the soil microarthropods community decreased with fire intensity, and fire intensity also affected the composition 
of the arthropods and collembolan families. Isotomidae and Onychiuridae were present only in the burnt stands. The number of families decreased with increasing fire intensity: Isotomidae being dominant and some Entomobryidae, Hypogastriridae and Onychiuridae found in light fire, Isotomidae lowered to some extend and Hypogastruridae and Onychiuridae disappeared in medium fire and finally in the high fire intensity all collembolan representatives disappeared. We were not able to determine a fire intensity of the wildfire, but results of our study showed similar pattern in occurrence of collembolan groups with a light fire. On the other hand, Malmström (2008) studied temperature tolerance in soil microarthropods simulating forest-fire heating in the laboratory and found that among Collembola $F$. mirabilis was the most heat-tolerant species. In our study the species had, however, very low abundance at burnt stands. Admitting results of the previous author, we assume that despite higher survival of fire disturbance, F. mirabilis does not prefer changed conditions in the soil after fire.

Henig-Sever et al. (2001) and Kim and Jung (2008) also found a direct relationship between fire intensity and the $\mathrm{pH}$ of the ash layer. The increase in $\mathrm{pH}$ of the ash directly related to the impact of fire intensity on the chemical properties of the forest floor. Soil $\mathrm{pH}$ was higher in burnt stands than in control stands in their study due to release of mineral substances as oxides or carbonates usually having an alkaline reaction. They also observed that the abundances of oribatid and gamasid mites and collembolans negatively correlated with the soil $\mathrm{pH}$. Similarly, we recorded increased soil $\mathrm{pH}$ in burnt stands compared to unharmed reference forest stands, however, with $\mathrm{pH}$ values in windthrown clear-cut stands being the highest. On the other hand, we did not find any correlations between soil $\mathrm{pH}$ and collembolan abundance. We recorded positive correlations between the abundance of several species and soil nutrients, mostly calcium and phosphorus. Similarly, Geissen et al. (1997) found positive correlations between abundances of one collembolan species group (Onychiurus furcifer, Folsomia qundrioculata and Isotoma notabilis) and the concentrations of potassium and, to a certain extent, phosphorus, while abundances of the second group (Onychiurus quadriocellatus and I. minor) were negatively correlated with the content of basic cations or the $\mathrm{pH}$ value. Generally, it is difficult to explain the reason of such correlation observations due to the indirect effect of soil nutrients on particular species.

The presented results are based on the case study of edaphic Collembola in Central European mountain spruce forests after disturbance. The sampling design of the study was adapted to the local natural conditions, especially to the smaller extent of the area affected by fire (continuous area of 229 ha). Therefore, sampling plots resemble pseudoreplicates. We could obtain more reliable data on the effect of forest disturbance/treatment by sampling in different (more distant) locations; however, the burnt area was limited in extent. On the other hand, pronounced effects of particular disturbances studied (wildfire, deforestation) were documented not only by quantitative parameters of the communities (abundance, species richness). We also observed apparent differences between treatments in species composition and structure of edaphic Collembola communities with several indicator species strongly supporting the effect of the treatment studied. Probably, including more replicate plots would validate the observation.

Finally, in spite of the limitations outlined, the present paper contributes to the understanding of fundamental knowledge on the effects of forest wildfire and clear-cut management on communities of soil fauna.

\section{Conclusions}

The present study showed that in European montane spruce forests, following a 2 year period of recovery, wildfire may cause a temporary increase in the abundance and species richness of soil Collembola compared to clear-cut windthrown forest stands and to unharmed reference forest stands. Moreover, soil conditions after wildfire may be more favourable for rare or less abundant species. Direct effects of fire disturbance (immediate mortality of soil animals) have probably lesser impact to collembolan communities than the indirect effects of soil type, soil microclimate, nutrient content and biological interactions. Changed conditions in the disturbed forest are reflected in the composition and biomass of the herb vegetation as well as in the composition of the soil biota as the consequence of different trajectories of the secondary succession after the disturbance. The investigations presented in this study represent a part of the long-term observations of soil arthropods that may bring more light to mode of the secondary succession of the soil fauna in the mountain spruce forests differently affected by natural and human disturbance. The long-term study of soil Collembola communities in disturbed forest stands may have wider implications for the better understanding of forest ecosystem dynamics after perturbation.

Acknowledgements The study was supported from the Slovak Scientific Grant Agency VEGA project no. 1/0019/08. The authors are very grateful to Dr. Karel Tajovský and prof. Dr. H. Šantrůčková (České Budějovice, Czech Republic) for their kind help with the soilchemical analyses. Dr. Kieran Green (UK) is acknowledged for comments and linguistic correction of the manucript. 


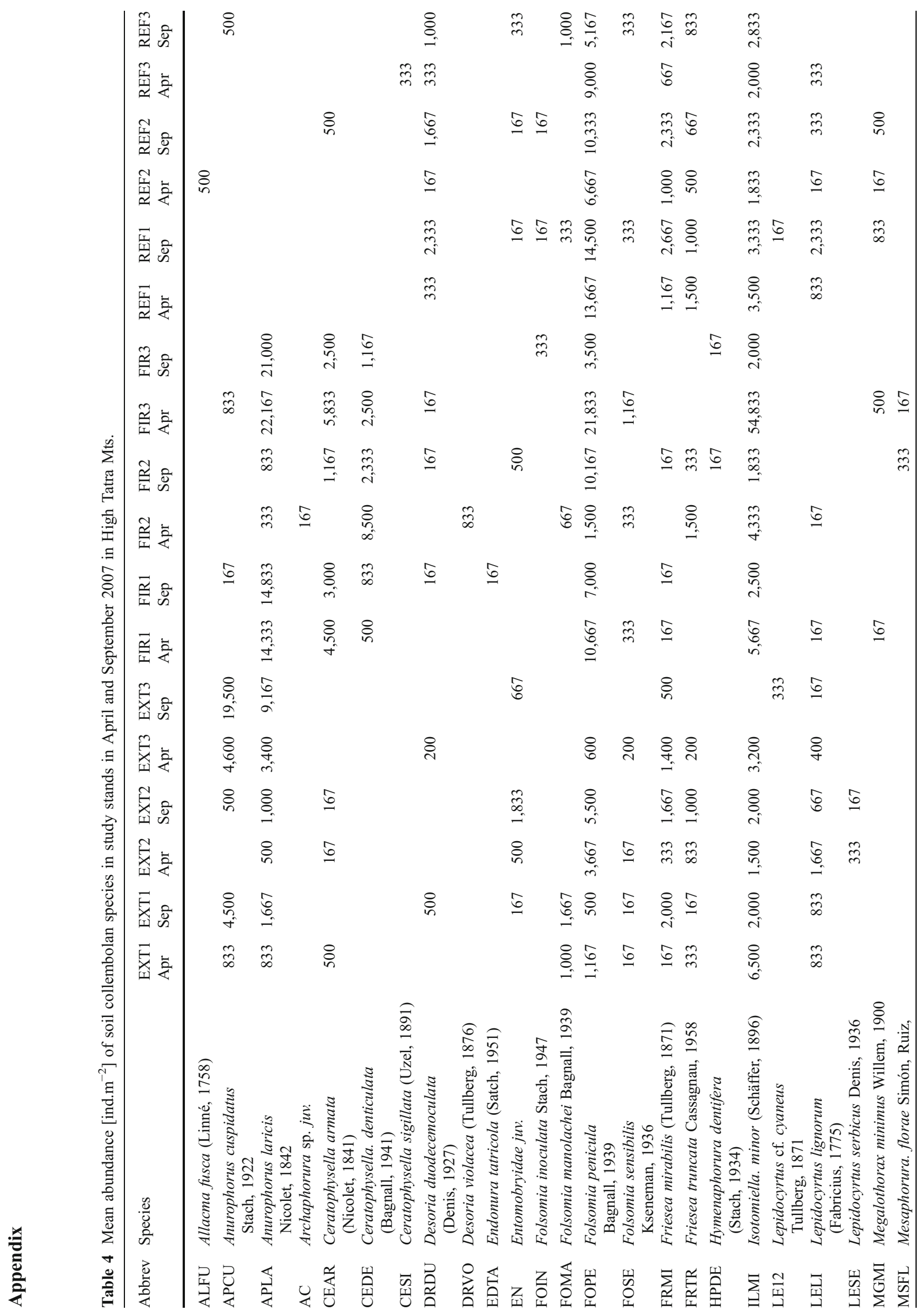




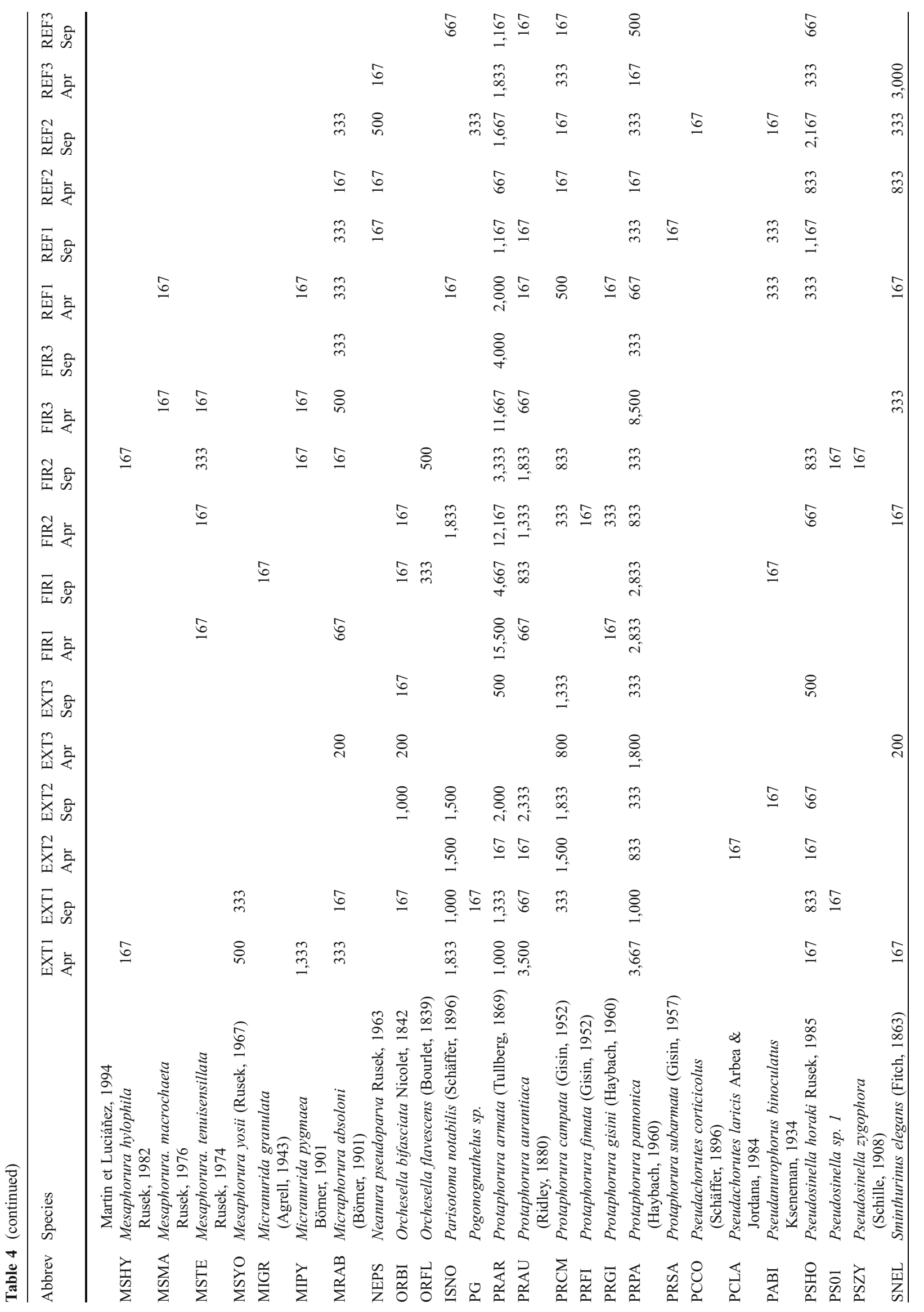




\section{References}

Bretfeld G (1999) Symphypleona. In: Dunger W (ed) Synopses on palaearctic Collembola, vol. 2. Abhandlungen und Berichte des Naturkundemuseums, Görlitz, 318 p

Certini G (2005) Effects of fire on properties of forest soils: a review. Oecologia 143:1-10

Čerevková A, Renčo M (2009) Soil nematode community changes associated with windfall and wildfire in forest soil at the High Tatras National Park, Slovak Republic. Helminthologia 46:123-130

Coleman TW, Rieske LK (2006) Arthropod response to prescription burning at the soil-litter interface in oak-pine forests. For Ecol Manag 233:52-60

Crossley DA, Blair JM (1991) A high efficiency, "low-technology" Tullgren-type extractor for soil microarthropods. Agric Ecosyst Environ 34:187-192

Čuchta P, Kováč L, Miklisová D (2009) The effect of windthrow in the spruce forests of the High Tatras (Slovakia) on soil microarthropods one year after a severe wind calamity with special reference to Collembola (Hexapoda). In: Tajovský K, Schlaghamerský J, Pižl V (eds) Contributions to soil zoology in Central Europe III. ISB AC CR, v.v.i., České Budějovice, pp 13-18

Dress WJ, Boerner REJ (2004) Patterns of microarthropod abundance in oak-hickory forest ecosystems in realtion to prescribed fire and landscape position. Pedobiologia 48:1-8

Dufréne M, Legendre P (1997) Species assemblages and indicator species: the need for a flexible asymmetrical approach. Ecol Monogr 67:345-366

Falt’an V, Bánovský M, Jančuška D, Saksa M (2008) Zmeny krajinnej pokrývky úpätia Vysokých Tatier po veternej kalamite. Geografika, Bratislava, 96 p (in Slovak)

Fjellberg A (1998) The Collembola of Fennoscandia and Denmark, part I: Poduromorpha. In: Kristensen NP, Michelsen V (eds) Fauna Entomologica Scandinavica, vol. 35, Brill, 184 p

FORTRAN (2004) IndVal or how to identify indicator species of a sample typology? http://old.biodiversite.wallonie.be/outils/indval/

Geissen V, Illmann J, Flohr A, Kahrer R, Brummer GW (1997) Effects of liming and fertilization on Collembola in forest soils in relation to soil chemical parameters. Pedobiologia 41:194-201

Gömöryová E, Střelcová K, Škvarenina J, Bebej J, Gömöry D (2008) The impact of windthrow and fire disturbances on selected soil properties in the Tatra National Park. Soil Water Research 3:74-80

Haimi J, Fritze H, Moilanen P (2000) Responses of soil decomposer animals to wood-ash fertilisation and burning in a coniferous forest stand. For Ecol Manag 129:53-61

Henig-Sever N, Poliakov D, Broza M (2001) A novel method for estimation of wild fire intensity based on ash $\mathrm{pH}$ and soil microarthropod community. Pedobiologia 45:98-106

Johnstone JF, Stuart Chapin F III (2006) Effects of soil burn severity on post-fire tree recruitment in boreal forest. Ecosystems 9:14-31

Kim JW, Jung C (2008) Abundance of soil microarthropods associated with forest fire severity in Samcheok, Korea. Journal of AsiaPacific Entomology 11:77-81

Králová M, Dražd’ák K, Pospíšil F, Hadačová V, Klozová E, Luštinec J, Kutáček M, Sahulka J (1991) Vybrané metody chemické analýzy půd a rostlin. Academia, Praha, 160 p (in Czech)

Kubíková J (1970) Geobotanické praktikum. UK, Praha, 186 p (in Czech)

Kunca A, Zúbrik M (2006) Vetrová kalamita z 19. novembra 2004. Národné lesnícke centrum, Zvolen, 40 p (in Slovak)

Kutiel P, Naveh Z (1987) The effect of fire on nutrients in a pine forest soil. Plant Soil 104:269-274

Mabuhay JA, Nakagoshi N, Isagi Y (2006) Soil microbial biomass, abundance and diversity in a Japanesse red pine forest: first year after fire. J For Res 11:165-173 
Malmström A (2008) Temperature tolerance in soil microarthropods: simulation of forest-fire heating in the laboratory. Pedobiologia 51:419-426

Malmström A, Perrson T, Ahlström K, Gongalsky KB, Bengtsson J (2009) Dynamics of soil meso- and macrofauna during a 5-year period after clear-cut burning in a boreal forest. Applied Soil Ecology 43:61-74

Murphy J, Riley JP (1962) A modified single solution method for the determination of phosphate in natural waters. Anal Chim Acta $27: 31-36$

Nedoma J (1990) Práce s iontově selektivními elektrodami. Rostlinná výroba 36:667-670 (in Czech)

Pomorski RJ (1998) Onychiurinae of Poland (Collembola: Onychiuridae). BS, Wrocław, $201 \mathrm{p}$

Ponge J-F (2003) Humus forms in terrestrial ecosystems: a framework to biodiversity. Soil Biology Biochemistry 35:935-945

Potapov MB (2001) Isotomidae. In: Dunger W (ed) Synopses on palaearctic Collembola, vol. 3. Abhandlungen und Berichte des Naturkundemuseums, Görlitz, 603 p

Rusek J, Brůhová J (2007) Impact of bark beetle outbreak on epigeic communities of Collembola (Insecta: Entognatha) in climax spruce forests in the Šumava National Park, Czech Republic. In: Tajovský K, Schlaghamerský J, Pižl V (eds) Contributions to soil zoology in Central Europe III. ISB AC CR, v.v.i., České Budějovice, pp 121-126

Sileshi G, Mafongoya PL (2006) The short-term impact of forest fire on soil invertebrates in the miombo. Biodivers Conserv 15:3153-3160
Sommers LE, Nelson DW (1972) Determination of total phosphorus in soils: a rapid perchloric acid digestion procedure. ProceedingsSoil Science Society of America 36:902-904

StatSoft, Inc. (2009) STATISTICA (data analysis software system), version 9.0. www.statsoft.com

Tahovská K, Kopáček J, Šantrůčková H (2010) Nitrogen availability in Norway spruce forest floor - the effect of forest defoliation induced by bark beetle infestation. Boreal Environmental Research: 15:553-564

Thibaud J-M, Schulz H-J, da Gama Assalino MM (2004) Hypogastruridae. In: Dunger W (ed) Synopses on palaearctic Collembola, vol. 4. Abhandlungen und Berichte des Naturkundemuseums, Görlitz, 287 p

Watanabe FS, Olsen SR (1965) Test of ascorbic acid method for determining phosphates in water and sodium bicarbonate extracts from soils. Proceedings-Soil Science Society of America 29:677-680

Wermelinger B, Duelli P, Obrist MK (2003) Windthrow stimulates arthropod diversity in forests. Proceedings of the International Symposium, May 29-31, 2003, Mantova, pp 79-82

Wikars L-O, Schimmel J (2001) Immediate effects of fire-severity on soil invertebrates in cut and uncut pine forests. For Ecol Manag 141:189-200

Zimdars B, Dunger W (1994) Tullbergiinae. In: Dunger W (ed) Synopses on palaearctic Collembola, vol. 1. Abhandlungen und Berichte des Naturkundemuseums, Görlitz, 71 p 